\title{
VREDNOTENJE VLOGE NARAVNIH VIROV (OKOLJSKEGA KAPITALA) SLOVENIJE V STRATEGIJI RAZVOJA SLOVENIJE Z VIDIKA KONKURENČNOSTI IN KAKOVOSTI ŽIVLJENJA
}

Po vstopu Slovenije v EZ se je pomembno spremenil pomen nekaterih njenih razvojnih potencialov, vključno z naravnimi viri. Urad RS za makroekonomske odnose in razvoj je leta 2004 razpisal natečaj za raziskovalno nalogo Vrednotenje vloge naravnih virov (okoljskega kapitala) Slovenije v Strategiji razvoja Slovenije z vidika konkurenčnosti in kakovosti življenja, ki naj bi za obdobje do leta 2013 (deset let po vstopu Slovenije v EZ) ocenil pomen ključnih naravnih virov. Strategija razvoja Slovenije naj bi med drugim podčrtala pomen razvojno in varovalno pretehtane rabe domačih naravnih virov. Odgovorni nosilec projekta je bil spodaj podpisani, $v$ interdisciplinarno zasnovani raziskovalni skupini pa so sodelovali Margita Adamič, diplomirana ekonomistka, Boris Kryštufek, diplomirani biolog, Barbara Lampič, diplomirana geografinja in Sašo Medved, diplomirani ing. strojništva.

Zaradi časovne omejenosti je bil poudarek raziskovalnega dela na ekonomskem, tehnološkem in okoljskem vrednotenju obstoječe baze podatkov o količini in kakovosti naravnih virov Slovenije in njenih pokrajin. Raziskava ugotavlja, da zaradi izjemne geografske raznovrstnosti in s tem povezane pokrajinske mozaičnosti ter geološke mladosti ozemlja razpolaga Slovenija z omejenimi, skromnimi zalogami neobnovljivih virov (zlasti fosilnih goriv) in raznovrstnimi obnovljivimi viri ter veliko biotsko raznovrstnostjo. Prostorska razpoložljivost ključnih naravnih virov kaže, da so v regijah Slovenije prisotni različni naravni viri, kar ocenjujemo kot strateško konkurenčno prednost Slovenije in pomemben dejavnik skladnejšega regionalnega razvoja ter kakovosti življenja.

$Z$ dvoplastnega vidika, torej glede na načrtovani dvig konkurenčnosti in kakovosti življenja (ožje - kakovost okolja) v obdobju do leta 2013 po količini in/ali kakovosti izstopajo naslednje sestavine okoljskega kapitala Slovenije:

- različni vodni viri - vodo oskrbna, energetska in turistično-rekreacijska funkcija;

- biomasa, zlasti lesna - industrijska, energetska in poselitvena funkcija;

- geotermalna energija - energetska in turistično-zdravstvena funkcija;

- zemljišča za pridobivanje kakovostne, zdrave hrane-kmetijska, ekosistemska in poselitvena funkcija;

- $\quad$ lignit - energetska, delno geopolitična (zmanjšanje uvozne odvisnosti) funkcija;

- naravne pokrajine - rekreacijsko-turistična funkcija;

- biotska raznovrstnost - ekosistemska, kulturološka in rekreacijsko-turistična funkcija.

Zaradi regionalne mozaičnosti (naravnogeografske in družbenogeografske, pokrajinskoekološke in razvojne) Slovenije in njenih regij so presoje ekonomskih, socialnih in okoljskih vplivov vseh načrtovanih rab posameznih virov okolja $\mathrm{v}$ specifičnih regionalnih neobhodne za sonaravno, optimalno rabo okoljskega kapitala.

Dušan Plut 